\title{
Is It Still Too Early to Tell? Rethinking Sociology's Relations to the French Revolution
}

\author{
DAVID INGLIS*
}

Je stále př́iliš brzy? Přehodnocení vztahů mezi sociologií a francouzskou revolucí

\begin{abstract}
It seems almost impossible today to deny the importance of the French Revolution in creating both the distinctively modern social world and sociology's characteristic responses to it. This paper takes issue with various of the standard narrations of these matters. It aims at developing fresh thinking about what the Revolution was, and what roles it may, or may not have, played in generating subsequent social phenomena and the sociology tasked with comprehending them. The claim by Robert Nisbet that the roots of sociology especially lie in Conservative responses to the Revolution are critically assessed. The potential importance of Durkheim and de Tocqueville for creating new narrations of the connections between the Revolution and sociology are considered. The manners in which the Revolution has been invoked to construct concepts of "modernity" and dramatic historical breaks with the past are reflected upon.
\end{abstract}

Keywords: Revolution; French Revolution; Sociology; History; Historical Sociology; Durkheim; de Tocqueville

DOI: $10.14712 / 23363525.2018 .36$

\section{Introduction}

One of the great political quotations may have been falsely attributed to the Chinese Communist leader Zhou Enlai. When he was supposedly asked in the 1960s about the significance of the French Revolution, he reportedly said it was still too early to tell. Yet it seems almost impossible today to deny the importance of the French Revolution in creating both the distinctively modern social world and sociology's characteristic responses to it. School and university textbooks describe the Revolution as one of the decisive events of modern history [Harison 2002]. If the Revolution is accepted, as it often has been, as the archetype of most subsequent revolutions, one may either celebrate it as the start of real human emancipation, introducing potentially all human beings to democratic government [Wagner 2012], or instead one can denounce it as the first historical manifestation of a seemingly inevitable slide of many revolutions into first mob rule and then totalitarianism [Nisbet 1974]. Beyond the specifically French case [Aron 2003], the French Revolution seems to pose at least two major questions for the study of revolutions in general - why do they usually turn out differently from how their instigators intended, and why are peaceful and idealistic intentions so often subverted by violence [Sztompka 1993]?

But just as Zhou's famous quote may be fictitious, so too many widespread assumptions about the significance of the Revolution, as the instigator of modernity and as the begetter of sociology, may also be problematic. This paper, and the other papers in this

Prof. David Inglis, Department of Sociology, Helsinki University. E-mail: david.inglis@helsinki.fi. 
special section take issue with various standard narrations of these matters. They do so with the aim of developing fresh thinking about what the Revolution was (or still is), and what roles it may, or may not have, played in generating subsequent social phenomena and the sociology tasked with comprehending them. Themes broached here include: the inevitability of the contingency of events, the changing nature of politics and power, the interplay of the sacred and secular, as well as the rational and irrational, and claims about the Revolution creating a radical historic break with the past, and being a crucible whereby both modernity and sociology were forged.

\section{Thinking about the Revolution}

Authors ranging through time and space have seemed, despite multiple ideological differences, to agree on the world-historical significance of the Revolution, whether more on the grounds of the philosophy of history or more based on empirical historiographical considerations [Krejči 2004].

Kant, for example, read the Revolution as "a sign or spectacle revealing the potential for autonomy characteristic of the human species" [Kouvelakis 2003: 2]. Hegel celebrated it as a "glorious mental dawn," because a new stage of Spirit had been reached whereby humans realized that "thought ought to govern [...] reality" [Hegel 1956: 447]. Marx regarded it as a major stepping-stone in the creation of a fully bourgeois social order, with Jacobin and Napoleonic centralization of state power working like a "gigantic broom" to sweep away the remnants of feudalism [Nisbet 1980: 138].

More recent students have seen the Revolution as both expression and creator of a "second Axial Age, in which a distinct cultural political and institutional programme crystallized and expanded throughout most of the world" [Eisenstadt 2004: 49]. The social consequences of the Revolution are seen to have set up for later generations knotty problems of liberty versus equality, of individual rights versus community and fraternity, and of class struggle versus social solidarity [Wagner 2008].

If the Revolution is widely thought to be so centrally a part of the making of what is conventionally called "modernity," reflection upon it involves profound questions of chronology and meaning did the "modern world" begin in 1789 [Evans 2007]? Does the Revolution have an end-point, or is its end "not yet in sight" [Toynbee 1987: 294]? Did it signify the "end of History," as some following Hegel, such as Alexandre Kojève, have maintained [Fukuyama 1992]?

The radical newness of the Revolution itself, of its consequences, and of the sort of society it helped forge, not just in France but around Europe and the wider world, has been widely assumed. This was done, first of all, by the revolutionaries themselves, than their critics - especially those of a Conservative bent - at the time and later, then by sociologists throughout the 19th and 20th centuries, and also by the majority of historians of sociology. Kumar [Kumar 1986: 19, 26] summarises the prevailing sentiments on the subject: "No other event in the history of modern times has so powerfully aroused the sentiments of novelty, transformation and the creation of a new order [...] [T] here was the sense that man [sic] stood on the edge of one of the most momentous transformations of all his history, that in the ideas and the events around him could be seen innumerable witnesses to this fact." 
This was the sort of view shared by the Revolutionaries, and those have who opposed them. The radical innovations of the Revolution were identified in the 1820 s by Thomas Carlyle [Carlyle 1980 (1829): 84]:

There is a deep-lying struggle in the whole fabric of society; a boundless grinding collision of the New with the Old. The French Revolution, as is now visible enough, was not the parent of this mighty movement, but its offspring. Those two hostile influences, which always exist in human things, and on the constant intercommunion of which depends their health and safety, had lain in separate masses, accumulating through generations, and France was the scene of their fiercest explosion; but the final issue was not unfolded in that country: nay, it is not yet anywhere unfolded.

Similar thoughts of a radical break with the past were expressed by Alexis de Tocqueville [Tocqueville 2008 (1856): 19] thirty years later:

What had [...] seemed to the rulers of Europe and the politicians an event not out of the ordinary in the life of nations, now appeared to be such a new event, in such opposition to all that happened before in the world, yet so widespread, so grotesque, so undecipherable, that the human mind looked at it with open disbelief. Some felt that this unknown power would drive human societies to their complete and terminal dissolution [...] It could not be arrested by men nor could it control its momentum.

The idea of the apparently radical newness of the Revolution - in its aims, nature, and ramifications - has entered into the conceptual fabrics of political theory and sociology. The French Revolution has come to define what counts as a properly "modern" revolution, rather than its converse, a pre-modern rebellion. In Hannah Arendt's [Arendt 1973] influential formulation, the American and French revolutions are revolutions in unprecedented and profound ways. They are the first historical exemplars of political processes involving a specifically "modern" consciousness of time, with that consciousness being expressed in the very term "revolution" itself. Before 1776 and 1789, the word referred - as it had done since ancient times - to a return to a point in a pre-determined historical cycle, rather than referring to new beginnings. But in the late 18th century in Europe and North America, a sense arose that "the course of history suddenly begins anew, that an entirely new story, a story never known or told before, is about to unfold" [Arendt 1973: 29].

For Arendt, the late 18th century revolutions, and their understanding and deployment of the term "revolution" itself are radical innovations, the first "revolutions" in the modern sense, partly because they embody a wholly new "revolutionary" consciousness. Revolutionary actors, especially in France, defined the Revolution as the creation of an unprecedented future involving a cataclysmic break with past arrangements. Precisely because actors, for the first time, believed what they were doing was radically new, and involved the creation of radical innovations in social life, then analysts too must define those revolutions as thoroughly new sorts of political phenomena, with thoroughly novel consequences for social order. Arendt's definitional interventions have been influential in subsequent studies of revolution. Partly through her writings have the Revolutionary actors' sense of their own radical newness gotten into the bloodstream of academic analyses, such that their self-understanding as unprecedented innovators creating a new world has often gone unchallenged. 


\section{Relating Sociology to the French Revolution}

If accepting the French Revolution as an exercise in radical, modernity-generating novelty is widespread today, so too is the idea that it was out of the responses to it by its critics, often the most hostile ones, that the very "modern" science of sociology was born. Different authors have emphasized varied aspects of that situation, but the core narrative remains the same. Friedrich Engels [Engels 1959: 351-352], for one, noted that "compared with the splendid promises of the Enlightenment philosophers, the social and political institutions born of the 'triumph of reason' were bitterly disappointing caricatures," and out of that sense of promises betrayed came the writings of Saint-Simon and Fourier, which would influence subsequent sociologists such as Durkheim. (For an alternative account of the effects of the Revolution in German universities and sociology, see both Lybeck and Roman, this volume.)

From a very different ideological position, Isaiah Berlin [Berlin 2000: 109] tells a related story. The perceived failures of the Revolution were the seedbed from which a new consciousness of society and history arose:

Although it promised a perfect solution to human ills, being founded [...] upon peaceful universalism [...] [and] the doctrine of unimpeded progress [...] it nevertheless did not go the way it was intended $[\ldots]$ and therefore what it attracted attention to was not at all reason, peace, harmony, universal freedom, equality, liberty, fraternity [...] but, on the contrary, violence, appalling unpredictable change in human affairs, [and] the irrationality of mobs.

One consequence was that scholars started to believe that there must be a huge amount of information about human being[s] hidden underneath the surface of social life, and social science aimed to dig those out. The failure of the Revolution to create the promised rational society suggested that both massive, invisible, uncontrollable forces and also mysterious, hitherto submerged phenomena, such as recalcitrant "human nature," had taken their revenge on the presumptuous revolutionaries. Laws of unintended consequences of human actions were now sought, in a universe that now looked more baffling, if not terrifying, than it did in the 18th century.

The notion that it was the Conservative reaction to the French Revolution that was to a major extent responsible for the genesis of sociology is especially associated with the American sociologist Robert Nisbet, who wrote on this theme and popularised it between the 1940s and 1970s. For Nisbet [Nisbet 1952: 168], the French Revolution had "something of the same impact upon men's [sic] minds that the Communist and Nazi revolutions" had in the 20th century.

Nisbet's claims in this regard were at first majorly driven by concerns about societal developments in his own time. In his first piece on such matters, Nisbet [Nisbet 1943] worried about the effects of World War II and its aftermath on US society, which for him included the vastly increased power of the State over social spheres, resulting atomization of the citizenry, weakening of intermediate institutions between individuals and the State, and increased potential for political despotism. All these factors had already been pointed to as consequences of the Revolution by Conservative thinkers like de Bonald and de Maistre in the years after 1789. History was in danger of repeating itself in the mid-20th 
century. It seemed to Nisbet urgent to ask, in light of which roles sociology might play in post-War social reconstruction, out of which materials sociology had been created at the turn of the 18th and 19th centuries. Nisbet's answer in the 1940s explicitly and self-consciously echoed the ideas of de Bonald and de Maistre: sociology studied those intermediate institutions of human groups, such as the family, religion, trade guilds and suchlike, that the Revolution had sought to destroy and that World War II was now in danger of eroding. Post-War sociology was defined by Nisbet as concerned with themes of social disorder, dislocation, and alienation, which were exactly the themes construed by the early Conservatives as the negative consequences of the Revolution.

In his wartime reflections, Nisbet argued that the Conservatism of de Bonald, de Maistre, and others yielded concepts that became the conceptual "central core" of sociology [Nisbet 1943: 156]. This process occurred at two levels. First, the Revolution, as an embodiment of Enlightenment thought, sought to abolish all aspects of traditional, feudal society. The radical Jacobin faction within the revolutionaries especially sought to abolish all intermediate organizations, with the state taking control of social functions previously carried out by bodies like the Catholic Church and the guilds. There was a concomitant spread across France and other parts of Europe of the new values of individualism and revolutionary nationalism. Second, the Conservatives were appalled at these innovations, which seemed to lead to the loss of all those features that make "society" stable over time, namely hierarchy, established order, and cultural tradition. Against the perceived political, moral, and more broadly "social" anarchy, the Conservative thinkers set out a counter-revolutionary programme. For Nisbet [Nisbet 1943: 162], "not until the range of traditional society in its plural forms suffered the destructive impact of the Revolution did a systematic interest in the social group [as such] arise," and from this situation developed the central conceptual fabric of sociology in the rest of 19th century.

In the early 1950s, Nisbet [Nisbet 1952: 167] elaborated on these issues:

Such ideas as status, cohesion, adjustment, function, norm, ritual, symbol, are [C]onservative ideas not merely in the superficial sense that each has as its referent an aspect of society that is plainly concerned with the maintenance or the conserving of order but in the important sense that all these words are integral parts of the intellectual history of European Conservatism.

On this view, the Conservative thinkers discovered or created the idea of "society" as such. The perceived disastrous consequences of the Revolution revealed to them what seemed to be the true essence of the realm of the social. It "is not a mechanical aggregate of individual particles subject to whatever rearrangements may occur to the mind of the would-be reformer. It is an organic entity, with internal laws of development and with infinitely subtle personal and institutional relationships. Society cannot be created by individual reason, but it can be weakened by those unmindful of its true nature, for it has deep roots in the past" [Nisbet 1952: 169].

Nisbet goes on to list the list of attributes of "society" which the Conservatives identified precisely because the Revolution was in the process of apparently destroying them, all of which would become central themes in sociology: the primacy of society over the individual; the idea that society is irreducible to its various parts; the interdependence of all social phenomena; the notion that every social element, both institutions and individuals, 
has a given function in the workings of the whole; social existence depends on intermediate groups and institutions, which regulate individuals in line with societal needs; the view that the individual is not sui generis but rather a thoroughly social product; suspicion of capitalism and urbanism as dissolving factors upon what was taken to be "social solidarity"; the claim that social order requires sacred supports, and that some form of "religion" is necessary social glue; and the idea that if social power is to be more than despotism, it requires the legitimacy of long-standing authority. All these were themes developed by the Conservative thinkers against Enlightenment themes of natural rights, individualism and rational reconstruction of society, as these were put into practice by the Revolutionaries in general, and espoused by the Jacobins in particular [Levine 1995].

Nisbet argued that the story of sociology's Conservative roots applied to the major French thinkers of the 19th century. According to his account, Comte took up the Conservatives' themes and - crucially for sociology - regarded the problems thrown up by the Revolution in French society as "social" in nature rather than purely political. Through Comte's influence, the "social" realm came into more explicit view, while the "problem of social order" began to become prominent as both object of analysis and policy puzzle to be solved [Nisbet 1943: 161]. For Nisbet, Comte more than anyone else made the themes of the Conservatives palatable to a broader public, partly by conjoining them to the rhetoric of social progress, and partly by construing them in a scientific idiom, recasting them as empirical research objects rather than as polemical categories. "The great achievement" of Comte

was to rephrase the problem of order in such a way as to bring to the fore not only the ethical importance of the intermediate groups [religion, family, guilds, etc.] but their theoretical value in the study of man. It was precisely those areas of human association most severely treated by the Revolution which became conceptually important in sociology. The conspicuous esteem in which Comte holds religious association, the family, and the community, as well as the modes of control which these groups embody, is the source of that more dispassionate interest in these entities which has been the core of contemporary sociology [Nisbet 1943: 162].

Nisbet likewise emphasized how Frederic Le Play transformed Conservative themes of social disorder and break down into "a set of concrete problems calling for rigorous field investigation" [Nisbet 1952: 173]. But the more crucial test case was that of Durkheim, undoubtedly one of the most major figures in the history of the discipline. If his work was greatly indebted to the Conservatives, then so too must major portions of the discipline itself. Nisbet argued that Durkheim's work was indeed indebted in that way. For example, Durkheim's account of social institutions creating and constraining individual actors, as well as his view of contemporary society as suffering from the effects of social disorganization, place him "securely in the Conservative tradition" [Nisbet 1952: 174].

The contemporaneous socio-political reasons for Nisbet's championing of the French Conservatives' role in the constitution of sociology were clear in the war-time writing. But they are far less so in his subsequent iterations of the story [Nisbet 1974; Nisbet 1980]. There the story is presented as if it were free from matters of pressing political urgency or the necessary selectivity in the narration that goes along with them. The story is presented as if the essential points about the Conservative tenor of the central concepts of sociology are so certain as to be unchallengeable: that was just the way it was, with nothing more to 
be said. The Conservative roots of the discipline have been subtly but surely naturalised by Nisbet in his later writings, and made to seem self-evident. So have the alleged nature of the French Revolution [an embodiment of Enlightenment thought, and essentially Jacobin], its social effects [essentially social disorder, both "real" and also as perceived by contemporary actors], and the conceptual core of sociology [essentially a science of intermediate social groups, and of the problem of the lack of social order which undermines them].

\section{After Nisbet: Reconsidering Durkheim on the Revolution}

This is clearly a very partial interpretation of all these issues. Dissatisfaction with it provoked Anthony Giddens' [Giddens 1976] critique of what he called the "myth of the Conservative origins of sociology." For Giddens, Nisbet does not adequately differentiate between, on the one side, the ideas an author inherits from previous thinkers in her intellectual sphere, and which she is constrained to think with (and against), and, on the other side, the uses s/he makes of them and the resulting intellectual content that comes out of the engagement. The ideas that Durkheim grappled with may have been partly Conservative in origin, but that does not make them "Conservative" as such once they have been through the transformative crucible of Durkheim's engagement with them.

For Giddens [Giddens 1976], Nisbet's narration relies too much on Durkheim's debt to Comte. While the latter did indeed explicitly engage with the ideas of de Bonald, de Maistre, and similar others, Durkheim rejected much of the hierarchical vision of Comte as to how society in future should be organised, because in Durkheim's view contemporary society cannot return to any idealized pre-Revolutionary past of the kind Conservatives dreamed of. Giddens notes that the Saint-Simonian socialist strain of ideas in Durkheim's thinking is too conveniently underplayed - and it too was a direct response to the social consequences of the Revolution. Nisbet's narration also fails to deal with the fact that Durkheim not only promoted moral individualism as the basis of modern social order - when any individualism was anathema to the Conservatives - but that he saw it as a positive outgrowth of long-term societal evolution, which is a very different view from the Conservative one of a post-Revolutionary lapse into societal anarchy. What Nisbet's account precludes is consideration of how a major thinker like Durkheim created sociology as an exercise in liberal or reformist, socialist Republicanism, which are themselves as much products of the Revolution as are the concepts derived from the Conservatives.

We could develop that line of reasoning by saying that, while the Conservatives saw the Revolution as a dissolving agent, undermining all that was socially beneficial, Durkheim as a committed Republican saw it more like a set of promises still to be fulfilled. While Durkheim had to deal with social phenomena in France that could be traced directly back to the Revolution [Mazlish 1989: 200-201], nonetheless living a century after the Revolution, he could discern certain things about it that the Conservatives could not see from their vantage point.

Already in the 1850s Tocqueville [Tocqueville 1856] had noted the strongly religious idiom that the Revolutionaries had operated with. Robespierre presented to the revolutionary audience the notion that everything was being done by the precepts of a Supreme Being [Baehr 2002: 70]. Revolutionary principles and rhetoric were not at all purely secular, or simple expressions of Enlightenment rationalist philosophy. As Arendt [Arendt 1973: 185] 
noted, both the French and American Revolutions invoked "religious" sentiments at the very point of their apparently rendering politics decisively secular. Tocqueville stressed the religious nature of the Revolutionaries' rhetoric, the secular and the sacred being intertwined in complex ways, consideration of which later helped Durkheim to think through the religious nature of the (apparently secular) social realm, and the social nature of the (apparently ethereal) sacred realm. Tocqueville could diagnose the religious quality of the secular rhetoric as deriving from the fact that, perhaps for the first time in history, this was a revolution that aspired "to universal validity [...] claim(ing) to be the way of salvation for all humanity" [Aron 1972: 208]. It was this messianic quality, expressed in claims that the Revolution was far from being only for the French but was universal in scope, which particularly upset Edmund Burke and other Conservative observers at the time.

By Durkheim's period, it was possible to conceive of the Revolution as an awakening of, and exercise in, civil religion, which was ambivalently pitched between secular and sacred principles, abolishing traditional religion while still being recognizably "religious" in nature. If the contents of Christian belief had been removed, the structural form of religion - a strong conception of the division between sacred and profane, and collective, public rituals - remained and was forcefully given new contents by the Revolutionaries. This reworking of religion in the Revolution had already informed Comte's system, where sociology was fused with a religion of "humanity," the nature of which was ironically revealed by T. H. Huxley's quip that it was essentially "Catholicism without Christianity."

For Durkheim the "religion" of the Revolution was not the atheistic dissolving of belief that contemporary Conservatives had abhorred, but was, in fact, a variant of the overall species of "religion" that their thinking had in fact adulated, being just as much as Christianity a combination of beliefs and practices which bind human groups together. The value for Durkheim of considering the Revolution is that it reveals phenomena rarely so clearly visible in human affairs:

We can see society and its essential ideas become the object of an actual cult directly [...] Society's capacity to set itself up as a god or to create gods was nowhere more visible than in the first years of the Revolution. In the general enthusiasm of that period, things that were purely secular in nature were transformed by public opinion into sacred things: homeland, liberty, and reason. A religion propelled by its own momentum was established with its dogma, symbols, altars and holidays [Durkheim 1912: 161].

The Revolutionary principles of liberty, equality and fraternity were themselves articles of faith, as Durkheim noted [Goldberg 2011]. For him they were expressions of socially-oriented moral individualism, not the selfish, atomizing individualism loathed by the Conservatives. The Revolutionary principles were intended to become the moral foundations that could keep post-Revolutionary society bound together. It was not only Conservatives who realized that some sort of moral system had to be created to avoid total anarchy. The Revolutionary leaders themselves were aware of such considerations - an issue underplayed in Nisbet's account. From early on in the revolutionary process, they sought to control the crowds in Paris and the provinces through festivals and public rituals [Censer - Hunt 2005].

How subsequent European sociological thinkers dealt with the revolutionary crowds fits well enough with Nisbet's narration. For example, Le Bon's infamous reflections on the irrationality of crowds are very much centered upon a negative construal of the 
revolutionary waves between 1789 and 1793, leading him to conclude that all revolutions are nothing but irrational crowds with demagogic heads leading them - exactly what the contemporaneous Conservatives thought [Martindale 1967]. But if we look at the revolutionary masses through the eyes of more sympathetic observers, or through the eyes of the Revolutionary actors themselves, a different picture emerges. Heilbron [Heilbron 1995: 117] captures the sense of possibility well:

For a while, it looked as if the whole world could be reshaped. Forms of address were changed, and everyone had to say $t u$ or toi. Streets and cities were given new names, people solemnly shed the names with which they had been baptized, churches were turned into assembly halls or stables $[\ldots]$ and there was now a new calendar with ten days to the week and new names for the months. Everything (apparently) reminiscent of the Catholic and feudal past was eradicated. With new names for time and place, the world looked very different indeed.

It is this sense of the Revolutionary crowds that Durkheim [Durkheim 1912] found inspiration in. The Elementary Forms of Religious Life weaves together in a complex way Australian aboriginal life and the early days of the Revolution. The common denominator in both is their alleged capacity to reveal the essential components of human social life per se. The Revolution is for Durkheim a naturally-occurring experiment in how all societies work.

It may be a time when "people live differently and more intensely than in normal times," such as when "the most mediocre and inoffensive burgher is transformed into a hero or an executioner" [Durkheim 1912: 158]. But it also teaches us about the normal functioning of social life too. For example, consideration of the actions of the Revolutionary crowds reveals how "all parties [...] deliberately hold periodic meetings in which their members may renew their common faith by some collective demonstration" [ibid.]. Durkheim has in mind the oratory of the Revolutionary leaders when he theorizes about the dynamics of group formation and collective effervescence: think of "the special attitude of the man who speaks to a crowd - if he has managed to enter into communion with it [...] He feels filled to overflowing with an overabundance of forces that spill out around him [...] He is no longer a simple individual speaking, he is a group incarnate" [ibid.].

Durkheim also focuses on how the Revolutionary process seeks to do away with the old social coordinates and put new ones in their place. Time, for example, is de-naturalized and made subject to human agency by being revealed to the Revolutionaries - and then to the analyst who studies them - as a social institution, which needs to be reformed through a new calendar with novel time categorizations and new names for them. The old cloak of naturalness is flung off, as a new mode of constructing, then re-naturalizing, time is put into practice: "The divisions into days, weeks, months, years and so on correspond to the recurring cycle of rituals, holidays and public ceremonies. A calendar expresses the rhythm of collective activity while ensuring its regularity" [Durkheim 1912: 12].

If Durkheim's sense of "society" (structures, functions, solidarity, etc.) partly comes out of Conservative thought's reaction to the Revolution, as Nisbet says, then his sense of the social creation of the categories by and through which societies operate is directly influenced by the Revolution itself, in its destruction of the old contents of categories like time, and the invention of new contents to fill them up anew. For all the apparent newness of the Revolutionary calendar, and the other social and cultural features and consequences 
of the Revolution, they are only novel as contents. They do not change the fact that such categories are trans-historical and universal. The Revolution shows that all social and cultural innovations are at the level of cultural content, not social form. The same formal categories (time, space, etc.) and social substances (rituals, collective effervescence, etc.) exist in all societies, and cannot be "revolutionized" per se. Only the contents can be radically changed, as the events after 1789 attest. All of the key features of society remain in place - rituals, worship, collective effervescence - even if the contents and objects of those have changed from medieval Christianity and the divine right of Kings, to the new cult of the Citizen Perhaps this is a more deeply "conservative" thought than that held about the Revolution by the Conservatives. They envisaged a disastrous but fundamental and substantive change from the ancien regime to the revolutionary society, assuming a radical break between the two. Durkheim, by contrast, seems to discern a fundamental change in the cultural contents of categories before and after 1789, but for him, post-Revolutionary society still has all the same formal properties of pre-revolutionary society. People still worship entities that are thoroughly social in nature and in orientation, they still come together in collective rituals, they still find their bearings through categories like time, the contents of which are socially created, and so on. "Modern" society is formally no different from that which pertained in the pre-Revolutionary past, or indeed in Aboriginal Australia. The "break" of 1789 is radical in one way (i.e., culturally), but not at all radical in another (at the level of society's essential properties).

\section{On Continuities, Not Breaks}

It is feasible that Durkheim's thinking in this vein was influenced by Tocqueville's [Tocqueville 2008] arguments about what he regarded as the real nature and consequences of the Revolution. There he offered what was perhaps the first full-blown sociological explanation of the historical events leading up to the Revolution and its aftermath, examining the class relations and structural conditions which together created the conditions of possibility for the Revolution. According to Tocqueville [Tocqueville 2008: 7], no nation

has devoted more effort than the French in 1789 [...] to create a gulf between what they had been up to that point, and what they sought to be from then on [...] [T] hey adopted all kinds of precautions to avoid carrying anything of their past into the new state [...] so as to form an identity quite different from that of their forefathers. [...] they neglected nothing, so as to make themselves unrecognizable.

The Revolutionary actors expended much effort to convince themselves that the society they were creating was totally different from the one that the Revolution had supposedly abolished. And yet "unintentionally, they exploited the remnants of the old order to erect the structure of the new order" [ibid.]. While invoking the name of liberty, the Revolution led to massive centralization and the great expansion of the State apparatus of the ancien regime. This in Tocqueville's view leads to precisely the sort of social atomization and the potential for State despotism which preoccupied Nisbet in the 1940s. A revolt against governmental power thus led to a form of administrative centralization that massively strengthened it. Tocqueville and Durkheim seem to gesture towards a similar point: the Revolution was intended by its leaders to create a radical break with the previous social 
order, but it did not. Instead, it greatly expanded elements of the previous society, even if the similarities were denied or ignored by them and their descendants. The issue of continuities across time, rather than a massive break between one social order and another, will be returned to below.

According to Aron [Aron 1972: 206-207], Tocqueville was also concerned to discern the limits of sociological explanations of the Revolution: "Great events are explained by great causes but $[. .$.$] the details of events are simply events [...] not deducible from the$ structural facts of the society in question." As Moore [Moore 1966: 108] put it, "the whole process could have worked itself out very differently." This theme has been taken up again in recent years by Sewell [Sewel 1999], who has sought to use the French Revolution as a test case for elaborating "eventful" sociology, which avoids reducing shorter-term events to grand, macro-level structural causes.

It has also been taken up by the French historian Francois Furet [Furet 1981; Furet 1988], whose work has challenged standard historical accounts of the Revolution, especially Marxist ones, and in so doing has considerable potential for rethinking the French Revolution's relations to sociology. Furet's critical fire is concentrated on the Marxist understanding of the French Revolution as a "bourgeois revolution." This robs the events of the period of their specificity and "eventfulness," and of the possibility of being any different from how they happened to have turned out. The Revolution is reduced to being simply the inevitable conquest of state power by a bourgeoisie already in de facto control of French society, which is a radical simplification of the actual, much more complex situation.

For Furet, the Marxist conception also indicates that Marx arbitrarily refused to countenance - in his analysis of the Revolution, and more generally - the possibility of the autonomy of politics from socio-economic structures and the class contradictions of developing capitalism. As MacVarish [MacVarish 2005: 494] summarises Furet's points, the notion of "bourgeois revolution" as "an objective break in the continuity of history" reproduces the "subjective" discourse of the Revolution itself. It "makes the Revolution speak the task that history has assigned it [...] the task of ushering in capitalism through the agency of the bourgeoisie."

Marx's thinking here bears clear debts to Hegel's understanding of the Revolution as a key staging-post in the unfolding History of the Spirit [Marcuse 1963]. For Furet, Marx very unhelpfully conjoins a grand socio-economic account of the causes and consequences of the Revolution, in which its assigned task is to foment the transition from feudalism to capitalism, together with a political narrative of specific and potentially contingent events. The Marxist conception of the Revolution tries to pass off both levels, or modes of narration, as coterminous and parts of the same overall explanatory schema. For Furet, this conflation is precisely what should be avoided. This is not just because the "eventfulness" of events must be rescued from the grand teleological narrative. It is also because the political narrative is faulty too: it is wholly caught up in the Revolution's self-understanding, reflecting the various positions taken by the actors in the events themselves. Rather oddly, the Marxist account of the Revolution as an objective break in history, from feudalism to capitalism, takes the Revolutionaries' self-understandings, centered on creating a wholly new social order, at face value. Their "subjective" apprehension of the radical newness of Revolutionary society is displaced onto, and implicitly made to justify, the alleged newness of the society that Marxism assumes the Revolution has "objectively" created. 
Bruno Latour [Latour 1993] in the polemical book We Have Never Been Modern, which partly takes inspiration from Furet's skepticism about historical breaks, glosses Furet's point thus: the "actors and chroniclers of 1789 used the notion of revolution to understand what was happening to them, and to influence their own fate [...] the idea of Revolution led the revolutionaries to take irreversible decisions that they would not have dared take without it." Then, in the 19th and 20th centuries, "the revolutionary reading of the French Revolution [...] [was] added to the events of that time [...] and has organized historiography since 1789" [Latour 1993: 41].

To escape from these various conceptual confusions, Furet recommends developing a "conceptual history" of the Revolution. For Furet, this was already pioneered by Tocqueville, who asked the question which potentially gets us out of these various conceptual muddles: "What if the discourse of a radical break reflects no more than the illusion of change?" Or, in Latour's terms, what if the "events of 1789 were no more 'revolutionary' than the modern world has been 'modern'?” [ibid.].

\section{Revolution and Conceptual Conflation}

A similar note of scepticism is expressed by Wallerstein [Wallerstein 1987: 320] when he takes aim at what he regards as the simplistic assumption, widely spread in sociology, that the end of the 18th and the beginning of the 19th centuries "represent a crucial turning point in the history of the world, in that the capitalists finally achieved state societal power in the key states" of France and England. Wallerstein criticises how too often in sociology simplistic conceptualizations of events called "the French Revolution" and "the Industrial Revolution" (taken to be an "English" innovation) are invoked and then yoked together. The conjunction is itself based on a further assumption, akin to that which Furet had criticised in Marxism: "That capitalism (or its surrogate, individual freedom) had in some sense to 'triumph' at some point within particular states" [Wallerstein 1987: 321].

It is assumed, rather than demonstrated, that the two so-called "Revolutions" involved the overcoming of a mismatch between the bourgeoisie's economic dominance and its lack of state power, with the French Revolution solving the problem by making possible and expressing bourgeois capture of State mechanisms, thus creating a new entity, the capitalist state. For Wallerstein, "a remarkably large proportion of world history (writing) has been devoted to these two 'events', which are in fact dubious concepts rather than real entities or processes, while "an even larger proportion has been devoted to analysing other 'situations' in terms of how they measure up to those two 'events'" [ibid.].

This is unsatisfactory for Wallerstein because the terms "French Revolution" (FR) and "Industrial Revolution" (IR) are themselves at best markedly simplifying and are certainly open to question. Their deployment leads to overly schematic formulations, such as: $I R$ necessitates $F R$, and $I R$ is the consequence of $F R$ (or vice versa), which have unfortunately informed disciplinary common-sense. Confusion develops further when one remembers that the initial term "Industrial Revolution" in turn begat multiple spin-off concepts, such as industrialization as a general process, take-off periods, and suchlike terms, all of which are assumed to be connected to the French Revolution in one way or another, however unclearly specified. 
In a similar skeptical vein, Kumar [Kumar 1986: 46] reminds us that it was the French thinkers of the early 19th century, such as Saint-Simon, who, "by analogy with their own Revolution of 1789, were the first to hail the [...] (economic) changes (in England) as an 'Industrial Revolution' and to make the influential bracketing of the two as a single, all-embracing, world-historical phenomenon." In other words, what later would be called "modernity" was generated by first inventing the concepts of the two Revolutions, one socio-economic and the other political (but with wide-ranging social consequences), and then conjoining the two, in the process creating a thoroughly "modern" totality of politics, economics and social relations. This was assumed to indicate and embody a thorough break with all elements of the pre-Revolutionary past.

Following Kumar, we can say that this conceptual "invention of modernity" was deeply problematic at various levels. Once socio-economic and political-social processes were rendered into the concepts "French Revolution" and "Industrial Revolution," they were "taken out of the realm of history proper and equipped with the mantle of ideology, or myth [...] (becoming) a rallying cry, a programme for action, a justification" rather than neutral or reliable social scientific categories [Kumar 1986: 47]. As a result, the "French Revolution" began to be "seen as but one expression of an overall transforming tendency affecting all European societies. It belonged [...] not just to France, but to Europe and indeed the whole world." English socio-economic conditions were likewise transformed into the concept of "Industrial Revolution," which then mutated into the more general term "industrialization" that led in turn to the generic notion "industrial society," and that eventually transmogrified into the even more general term "modern society" [Kumar 1986: 5-55].

A further series of conflations were hidden in such generic concepts, while simultaneously making them possible. First, it was often assumed that the apparent egalitarian democracy of the "French Revolution" was "naturally" fitted with the Industrial economic order. This assumption was made because [what were taken to be] the two "Revolutions" were thought to have happened at roughly the same time as each other. But no such connection is either logically or empirically inevitable [Kumar 1986: 88-89].

Second, the separable - if empirically interconnected - histories of England (or the UK) and France were initially created as archetypes of each Revolution, and then conjoined in the "modern society" concept. Engels' famous footnote to the Communist Manifesto is just one expression of a much broader tendency that renders England paradigmatic of Industrial Revolution and France paradigmatic of Political revolution: "Generally speaking, for the economic development of the bourgeoisie, England is taken here as the typical country; for its political development, France."

When in both Marxist and non-Marxist forms of sociology, the two archetypes were conjoined, "an ideal bourgeois industrial order" was created. This concept was both unequivocal and ambiguous at the same time. It declared modern society's complete break with a feudal past. Yet, while "modern society" seemed to be expressed "with various degrees of strength and clarity in actual historical societies," it could not "be held to be coterminous with any one society or any precise tract of historical time." It figured rather as "a stage of social evolution, which finds embodiment in particular societies but embraces them just as it itself is comprehended (only) by the overall sequence and logic" of humankind's unfolding general history [Kumar 1986: 121]. So, as in the historical schemes of Kant, Hegel, and Marx, the French Revolution came to signify something else, something much 
bigger and broader than it, usually referred to using a concept involving capital letters, be it Human Reason, the Dialectics of Spirit, the Bourgeois Revolution, or Modern Society.

As Arnason [Arnason 1989] has noted, the French Revolution is the most potent symbol of one of the two different imaginaries that were conflated in the idea of "modern society," namely capitalism and industrialism abstracted from the English case, and political changes leading to democratic government, abstracted from the French case. Contemporary social theory and historical sociology have been faced with the choice of unpicking the conflation of the two imaginaries that was carried out in the 19th century. That unpicking can be done in at least two ways. First, by regarding each element as irreducible to the other, but seeing them as inexorably conjoined, such that "modernity" can be defined as involving the tension between the two. Or, second, one might regard each element as totally different from the other, with greatly differing histories [Wood 1999], and thus purely contingently related to each other [Wagner 2008: 80].

\section{Conclusion}

The controversies above will continue to be debated for some time. More generally we can say that the French Revolution has clearly been "good to think with" for intellectuals and polemicists for the last two centuries. Every generation has found in it differing forms of significance. Standard narrations of its significance - including for sociology - spring up and then harden into dogma or common-sense. Therefore, each new generation must challenge those narrations, which is what this paper and the others in this special section have sought to do.

One way to pursue such matters is to follow the lead of James [James 1939], which Reed [this volume] alludes to. This involves further developing accounts of how nonwhite actors from the French Caribbean colonies were actually more centrally and directly involved in the direction of the Revolution than was previously thought. The indirect agency of the rebelling slaves in Haiti, working together with the direct political pressure, regarding the extension of citizen rights to all people regardless of skin colour, exercised on the Parisian revolutionaries by the freed African slaves (gens de couleur), meant that the universalization of rights in the early 1790s was as much a "colonial" achievement as one emanating from the metropole [Go 2013: 47; Dubois 2000]. Recognition of this productively problematizes Eurocentric narrations not only of the Revolution but also of how and by whom sociology was created [Krause 2016].

More generally, it seems to me that, in light of what has been surveyed above, that the following questions should be posed in, and to, sociology at the present time:

Has sociology problematically constructed a historical break, between pre-modernity and modernity, which it sees as created - in significant part - by the Revolution? Has such a break taken the French Revolutionaries' claims of the radical newness of the society they were seeking to create at face value? What are we to make of the possible continuities stretching from before to after the Revolution, not just in France but elsewhere in so-called "modernity"? Is the break between "pre-modernity" and "modernity," which the Revolution supposedly signifies and partly makes possible, actually not as dramatically novel as it is often supposed to be?

Interesting answers to those questions are pointed to by the other papers in this special section. Taken together with this paper, they contribute to the current debate about the 
need to transcend simplifying "epochal" thinking in sociology, in order to gain more subtle accounts both of what we think "modernity" may be, and of what sociology's multiple relations to its prime analytical object may be [Inglis 2015]. It is not too early to tell that the French Revolution continues to be good to think with for those purposes, especially if one thinks against the grain of previously dominant interpretations.

\section{Bibliography}

Arendt, Hannah [1973]. On Revolution. London: Pelican.

Arnason, Johann P. [1989]. The Imaginary Constitution of Modernity. Revue Européenne des Sciences Sociales 27: 323-37.

Aron, Raymond [1965]. Main Currents in Sociological Thought. London: Pelican.

Baehr, Peter [2002]. Founders, Classics, Canons. New Brunswick: Transaction.

Berlin, Isaiah [2000]. The Roots of Romanticism. London: Pimlico.

Censer, Jack - Hunt, Lynn [2005]. Imaging the French Revolution. American Historical Review 110: 38-45.

De Tocqueville, Alexis [2008 (1856)]. The Ancien Regime and the Revolution. London: Penguin.

Dubois, Laurent [2000]. La République Métissée: Citizenship, Colonialism and the Borders of French History. Cultural Studies 14: 15-34.

Durkheim, Émile [2001 (1912)]. The Elementary Forms of Religious Life. Oxford: Oxford University Press.

Eisenstadt, Shmuel N. [2004]. The Civilizational Dimension of Modernity: Modernity as a Distinct Civilization. In. Arjomand, Said - Tiryakian, Edward A. (eds.). Rethinking Civilizational Analysis. London: Sage.

Engels, Friedrich [1959]. Anti-Dühring. Moscow: Foreign Languages Publishing House.

Engels, Friedrich [1968]. Socialism, Utopian and Scientific. In. Marx / Engels: Selected Works. London: Lawrence and Wishart.

Evans, Mary [2006]. A Short History of Society. London: McGraw Hill.

Fukuyama, Francis [1992]. The End of History and the Last Man. London: Hamish Hamilton.

Furet, Francois [1981]. Interpreting the French Revolution. Cambridge: Cambridge University Press.

Furet, Francois [1988]. Marx and the French Revolution. Chicago: University of Chicago Press.

Giddens, Anthony [1976]. Classical Social Theory and the Origins of Modern Sociology. American Journal of Sociology 81: 703-729.

Go, Julian [2013]. For a Postcolonial Sociology. Theory and Society 42: 25-55.

Goldberg, Chad Alan [2011]. The Jews, the Revolution, and the Old Regime in French Anti-Semitism and Durkheim's Sociology. Sociological Theory 29: 248-271.

Goldhammer, Jesse [2005]. The Headless Republic. Ithaca: Cornell University Press.

Harison, Casey [2002]. Teaching the French Revolution. The History Teacher 35: 137-162.

Hawthorn, Geoffrey [1976]. Enlightenment and Despair. Cambridge: Cambridge University Press.

Heilbron, Johan [1995]. The Rise of Social Theory. Minneapolis: University of Minnesota Press.

Himmelstein, Jerome L. [1981] Review: The Two Nisbets: The Ambivalence of Contemporary Conservatism. Social Forces 60: 231-236.

Inglis, David [2015]. Co je dnes v sociologii obhajitelné? Prezentismus, historická vize a proč je sociologie užitečná. Historical Sociology 1: 20-24.

Kouvelakis, Stathis [2003]. Philosophy and Revolution: From Kant to Marx. London: Verso.

Krause, Alison [2016]. "Western Hegemony" in the Social Sciences: Fields and Model Systems. Sociological Review Monograph Series 64: 194-211.

Krejčí, Jaroslav [2004] The Paths of Civilization: Understanding the Currents of History. London: Palgrave Macmillan

Kumar, Krishan [1986]. Prophecy and Progress. London: Pelican.

Latour, Bruno [1993]. We Have Never Been Modern. Cambridge: Harvard University Press.

Levine, Donald N. [1995]. Visions of the Sociological Tradition. Chicago: University of Chicago Press. 
MacVarish, Kathryn [2005]. Illusions of Revolution: Francois Furet's Critique of Marx. History of European Ideas 31: 491-508.

Marcuse, Herbert [1963]. Reason and Revolution. London: Routledge.

Martindale, Don [1967]. The Nature and Types of Sociological Theory. London: Routledge.

Mazlish, Bruce [1989]. A New Science: The Breakdown of Connections and the Birth of Sociology. Pennsylvania: Penn State Press.

Netter, Marie-Laurence [2003]. Raymond Aron and the French Revolution. European Journal of Political Theory 2: 373-382.

Nisbet, Robert [1943]. The French Revolution and the Rise of Sociology in France. American Journal of Sociology 49: 136-164.

Nisbet, Robert [1952]. Conservatism and Sociology. American Journal of Sociology 58: 167-175.

Nisbet, Robert [1974]. The Social Philosophers. London: Paladin.

Nisbet, Robert [1980]. The Sociological Tradition. London: Heinemann.

Sewell, William F. [1999]. Three Temporalities: Toward an Eventful Sociology. In. McDonald, Terence J. (ed.). The Historic Turn in the Human Sciences. Chicago: University of Michigan Press.

Toynbee, Arnold J. [1967]. A Study of History. Oxford: Oxford University Press.

Wallerstein, Immanuel [1987]. World-Systems Analysis. In. Giddens, Anthony - Turner, Jonathan (eds.). Social Theory Today. Cambridge: Polity.

Wood, Ellen Meiksins [1999]. The Origin of Capitalism. New York: Monthly Review Press.

David Inglis is Professor of Sociology at the University of Helsinki. Before that, he was Professor of Sociology at the University of Exeter and the University of Aberdeen. He holds degrees in sociology from the Universities of Cambridge and York. He writes in the areas of cultural sociology, the sociology of globalization, historical sociology, the sociology of food and drink, and social theory, both modern and classical. He has written and edited various books in these areas, most recently The Sage Handbook of Cultural Sociology and The Routledge International Handbook of Veils and Veiling Practices (with Anna-Mari Almila). He is founding editor of the Sage/BSA journal Cultural Sociology. His current research concerns the sociological analysis of the global wine industry. 